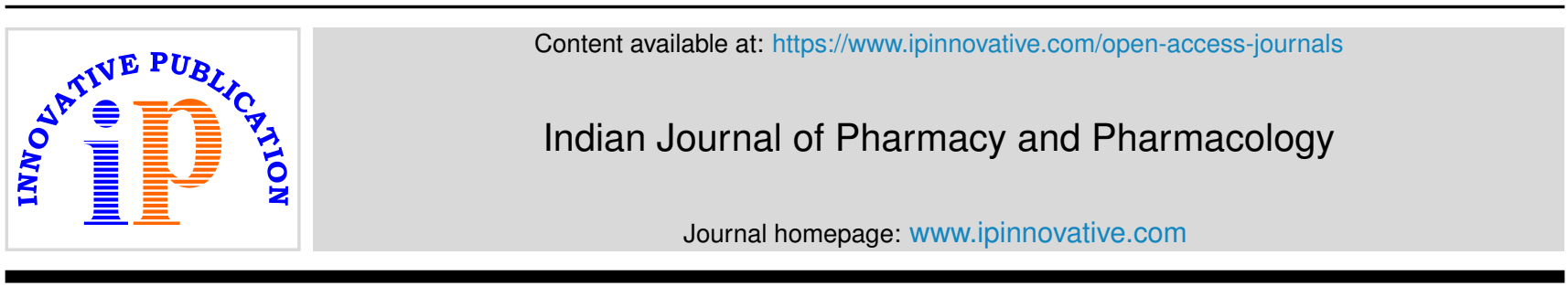

Original Research Article

\title{
Hypoglycemic and antidiabetic evaluation of leaves of phyllanthus distichus in normal and alloxan induced diabetic rats
}

\author{
Debashis Mohapatra $^{1, *}$, Sunita Mishra ${ }^{1}$ \\ ${ }^{1}$ College of Pharmaceutical Sciences, Baliguali, Puri, Odisha, India
}

\section{A R T I C L E I N F O}

\section{Article history:}

Received 18-08-2020

Accepted 22-08-2020

Available online 23-10-2020

\section{Keywords:}

Alcoholic Extract of Phyllanthus

Distichus (AEPD)

Antigen (Ag)

Alanine Amino Transferase (ALAT)

Alkaline Phosphate (ALP)

Asparatate Aminotransferase (ASAT)

Aqueous (Aq)

Body Wt

Direct Bilirubin (DB) Diabetes

Mellitus (DM)

Phyllanthus Distichus (PD)

\begin{abstract}
A B S T R A C T
The ethanolic extract of leaves of Phyllanthus distichus results maximum yield value than that of petroleum ether extract, chloroform extract through successive extraction process. The ethanolic extract of leaves of Phyllanthus distichus showed maximum control in blood sugar in hyperglycemic wistar rats than other experimental extracts. The test extract also reduces the blood sugar level to a maximum extent in case of normal animals. Among the study of effects of alcoholic extracts of leaves of Phyllanthus distichus in both normoglycemic and hyperglycemic model through oral route. Toxicological study revealed that the alcoholic extracts Phyllanthus distichus leaves were safe and does not alter normal physiological and behavioral effect even at a higher dose level of $3000 \mathrm{mg} / \mathrm{kg}$ body weight.

Administration of alcoholic extracts Phyllanthus distichus significantly reduces the elevated glucose level in alloxan induced diabetic rats confirms its anti-diabetic activity. This also reduces normal glucose level, which reveals the hypoglycemic property. The whole protein, whole cholesterol, ASAT, ALAT, ALP enzyme activity of alloxan administered rats showed significantly higher than normal rats, the test extract treated rats significantly reduced the elevated levels. The results of the present investigation indicate that the alcoholic extracts Phyllanthus Distichus leaves may have a place in the therapy of Diabetes Mellitus as anti-diabetic and/or hypoglycemic agent. The hypoglycemic and/or anti-diabetic effect of the test extract may be due to the influence on glycogenesis, glycogenolysis metabolic activity property of one or more of its constituents. Ethanolic extract of leaves of Phyllanthus Distichus is beneficial in lowering the blood sugar concentration and in the management of other diabetic complications without any doubt.
\end{abstract}

(C) 2020 Published by Innovative Publication. This is an open access article under the CC BY-NC license (https://creativecommons.org/licenses/by-nc/4.0/)

\section{Introduction}

The studies on the leaves of P.D. have not been reported on the antidiabetic activity. As for the above reason the present study was carried out on mice and rats and the dose fixation was done, as per the protocol.

1. Collection of leaves of P.D. and extraction of processes using different solvents according to their increasing order of polarity, for the present investigation.

2. Determination of the most potent extract for reduction of the elevated blood glucose levels induced by Alloxan in wistar rats by single dose treatment model through measuring the fasting blood sugar levels.

\footnotetext{
* Corresponding author.

E-mail address: dmohapatra911@gmail.com (D. Mohapatra).
}

3. Acute oxicity study of the potent extract of P.D to determine $\mathrm{LD}_{50}$ and selection of dose.

4. The route of administration in oral route by single dose treatment in both normoglycemic and hyperglycemic model.

5. Diabetes is induced by rat by single dose Alloxan administration.

6. Diabetes is confirmed by blood glucose estimation.

7. The study of hypoglycemic and/or antidiabetic activity of the most potent extract is to be done by the following models.

\subsection{Effect of test extracts on}

1. Single dose treated normoglycemic rats.

2. Single dose treated hyperglycemic rats. 
3. Single dose treated glucose loaded hyperglycemic rats.

4. Multi dose treated normoglycemic rats.

5. Multi dose treated hyperglycemic rats.

6. To estimate the glycogen conc. In liver and kidney.

7. Behavioural changes of animals after single dose treatment if any also to be performed.

8. Plasma lipids(TC,TG, LDL,HDL,VLDL) are to be analysed in diabetic rats to find out wheather any correction exits between the levels of these parameters and diabetes.

9. The changes in the levels of alkaline phosphate, aminotransferase(ASAT,ALAT), Total proteins, total bilirubin, direct bilirubin, albumin and globulin etc. are to be analyse in a serum.

10. Haematological parameters to be studied in the last day of treatment of subacute toxicity study.

11. Determination of percentage loss of body weights in alloxan induced diabetic rats treated with test extract at the end of 21 days.

The results obtained from control and experimental animals of the present investigation are compared and discussed in the light of available literatures.

\section{Materials and Methods}

\subsection{Plant collection and authentication}

Large number of leaves of Phyllanthus distichus appears in the month of July and November. Leaves were collected from the interior villages of Athgarh (Orissa). Before their use, they were carefully identified and collected.

\subsection{Preparation of the powder}

The leaves were dried over a polythene cover in shade drying method with a help of fan at $21^{\circ} \mathrm{C}$ room temperature and pulverized using a mechanical grinder. The powder is further passed through a fine mesh sieve to get a fine powder.

\subsection{Preparation of the extracts}

The powdered material $(600 \mathrm{gm})$ was extracted separately with different solvents of increasing order of polarity, e.g.. Petroleum ether, chloroform and ethanol by soxheletion method. The liquid extracts were concentrated under vaccum to yield dry extracts and preserved in a desicator till further experiments.

\subsection{Percentage yield of the extracts}

The leaves of Phyllanthus distichus was extracted with solvents of increasing polarity by Soxhlet apparatus. The percentage yield of the leaves of Phyllanthus distichus was found to be $2.66 \%, 1.66 \%, 14.66 \%$ and $12.66 \%$ with petroleum ether, chloroform, alcohol and water, respectively(shown in tab-1). The percentage yield of the ethanolic extract of Phyllanthus distichus was found to be greater $(14.66 \%)$ than extract with other solvent.

\subsection{Preparation of drug solution}

\subsubsection{Preparation of extract solution}

The semisolid extracts of P.D. and dissolved in sufficient quantity of solvent (Tween \& Normal saline). The aqueous extract of P.D. was dissolved in Normal saline and the latter were used for administration.

\subsubsection{Glibenclamide}

Glibenclamide $2.5 \mathrm{mg} / \mathrm{kg}$ b.wt was dissolved in sufficient quantity of solvent (Normal saline) and used in the treatment. 1

\subsubsection{Alloxan}

Alloxan $120 \mathrm{mg} / \mathrm{kg}$ b. wt was dissolved in the Normal saline and used to induce diabetes in rats. ${ }^{2}$

\subsection{Selection of aAnimals}

Healthy adult albino rats of wister strain weighing 150-200 gms and adult albino mice of swiss strain weighing 20-25 gms were selected for toxicological and anti-diabetic studies respectively with the approval from the instutional animal ethics committee (Regd. No.1171/C/08/CPCSEA).

\subsection{Maintenance of animals}

The animal house was well ventilated and animals had $12 \pm$ 1hour day and night schedule with temperature between $11-20 \pm 2^{\circ} \mathrm{C}$. The animals were housed in large spacious hygienic cages during the course of the experimental period. The animals were fed with rat pellets feed supplied by M/s Hindustan Lever Ltd., Bangalore, India and Aquaguard filtered water ad libitum. The place where the experiments we conducted kept very hygienic by cleaning with antiseptic solutions. The husk, which was for the purpose of keeping as a bed to the animals, was autoclaved and cleaned. Before the animals were kept, the cages (plypropylene) were also sterilized along with the water feeding bottles. As the diabetic animals are susceptible to infection hygienic condition were necessary.

\section{Experimental Setup}

\subsection{Hypoglycemic activity of AEPD in single dose treatment}

\subsubsection{In normoglycemic animal}

To check wheather the alcoholic extract of P.distichus is acting as an insulin secretagogue (Stimulation of insulin secretion from the pancreatic $\beta$-cell $\&$ to check the utilization). The study was carried out as mentioned Table 1. 
Table 1: Overnight fasted animals were grouped in 4 groups of 6 animals each groups

\begin{tabular}{lllll}
\hline $\begin{array}{l}\text { G roup } \\
\text { Gr-I }\end{array}$ & $\begin{array}{l}\text { Animal used } \\
\text { Albino rat }\end{array}$ & $\begin{array}{l}\text { S ex } \\
\text { M }\end{array}$ & $\begin{array}{l}\text { Body wt. } \\
200 \mathrm{gms}\end{array}$ & $\begin{array}{l}\text { T reatment } \\
\text { Served as control(Normal saline). Once } \\
\text { daily } \\
\text { Served as standard(Glibenclamide } \\
\text { Gr-II }\end{array}$ \\
Albino rats & M & $200 \mathrm{gms}$ & 2.5mg/kg)in p.o. Once daily \\
Gr-III & Albino rats & Test drug(p.o/i.p) Dose -1. Once daily \\
Gr-IV & Albino rats & M & $200 \mathrm{gms}$ & Test drug(p.o/i.p) Dose-2. Once daily \\
\hline
\end{tabular}

Blood glucose levels were measured in all 5 groups in diff. Time interval like 1, 2, 4, 8, $12 \mathrm{hrs}$.

\subsubsection{Alloxan induced diabetic animal}

To check wheather the Ethanolic extract of P.distichus has antidiabetic activity. The study was carried out mentionedTable 2 .

\subsubsection{Glucose loaded hyperglycemic animals}

It is a standard procedure used to monitor blood glucose levels over a period of time following glucose load.

To check wheather the ethanolic extract of P.distichus has hypoglycemic activity as mentioned Table 3 .

\subsection{Anti diabetic \& hypoglycemic study of extract of p.distichus in multi dose treatment}

\subsubsection{In normoglycemic animals}

To check wheather the ethanolic extract of P.distichus has hypoglycemic activity on the multiple dose treatment.

\subsubsection{In diabetic animals}

To check wheather the extract of P.distichus has antidiabetic activity on the multiple dose treatment in alloxan induced animals; the study was carried as mentioned Table 5.

\subsection{Toxicity studies}

\subsubsection{Acute oral toxicity studies}

The acute toxicity study is aimed to establish the therapeutic index i.e., the ratio between the pharmacologically effective dose and the lethal dose, and also to perform the primary screening.

The aqueous extract of Phyllanthus distichus was administered once orally at 4 dose levels $(500,1000$, $2000,3000 \mathrm{mg} / \mathrm{kg}$ ) to group of 10 mice of both sexes about equal in number which have been fasting overnight (about 18 hrs.)

The treated mice were observed continuously for two hours and then occasionally for further for four hours and finally overnight mortality recorded. ${ }^{3}$

During the course of study the behaviours of the mice were carefully observed and fall of time, reduction of spontaneous activity also determined. ${ }^{4}$

\subsubsection{Sub acute toxicity studies}

The purpose of this study is to determine the maximum tolerated dose and daily dosed for 3 to 4 weeks and to indicate the nature of toxic reaction of the drug.

In present study, the influence of Phyllanthus distichus extract on haematological parameters, a pathological change on 21 days dosing in Alloxan induce diabetic rats was carried out.

The diabetic rats were grouped into 6 of 6 animals each. Group 1 animals received solvent, Group III and Group IV was received AEPD and $200 \mathrm{mg} / \mathrm{kg}$ b. wt. p.o., once daily for 21 days.

At the end of the experimental period the blood was collected, serum separated and subjected to hematological and biochemical examination. ${ }^{3}$

\subsection{Investigation carried out in the present study}

Blood sample was drawn into tubes at different time intervals.

Serum was separated out by centrifugation and used in different estimations.

Diabetes was induced by a single dose of alloxan administration.

Blood glucose level, which is elevated in association with hyperglycemia diabetes, was measured to assess whether the plant extract has antidiabetic/hypoglycemic effect.

A significant body weight reduction is associated with diabetes hence the body weight was recorded before, during and after the treatment.

Acute toxic study was carried out to find out toxic symptoms of the extract and gross behavioural changes were also noticed.

Sub acute toxicity study was carried out to find out the influence of the extract on biochemical, haematological and histopathological findings.

ALAT, ASAT, ALP etc... were assayed in serum.

Serum lipids like total Cholesterol, HDL, LDL and VLDL, triglyceride were estimated.

Serum total protein and albumin were analysed.

Blood parameters like haemoglobin, RBC, WBC etc.... counts were determined

Clotting time was also determined 
Table 2: Overnight fasted animals were grouped in 4 gropes of 6 animals each groups.

\begin{tabular}{lllll}
\hline $\begin{array}{l}\text { Group } \\
\text { Gr-I }\end{array}$ & $\begin{array}{l}\text { Animal used } \\
\text { Albino rat }\end{array}$ & $\begin{array}{l}\text { Sex } \\
\text { M }\end{array}$ & $\begin{array}{l}\text { Body wt. } \\
200 \mathrm{gms}\end{array}$ & $\begin{array}{l}\text { T reatment } \\
\text { Served as control(Normal saline). Once } \\
\text { daily } \\
\text { Served as standard(Glibenclamide }\end{array}$ \\
Gr-II & Albino rats & M & $200 \mathrm{gms}$ & $\begin{array}{l}\text { 2.5mg/kg)in p.o. Once daily } \\
\text { Test drug(p.o/i.p) Dose }-1 . \text { Once daily } \\
\text { Gr-III }\end{array}$ \\
Gr-IV & Albino rats & M & $200 \mathrm{gms}$ & Test drug(p.o/i.p) Dose-2. Once daily \\
\hline
\end{tabular}

Blood glucose levels were measured in all 5 groups in diff. Time interval like 1, 2, 4, 8, $12 \mathrm{hrs}$.

(All these Rats are treated with Alloxan 110-150mg/kg i.p.prior to $72 \mathrm{hrs}$ )

Table 3: Overnight fasted animals were grouped in 4 groups of 6 animal each groups $\&$ glucose $(1 \mathrm{gm} / \mathrm{kg})$ was loaded to group II \& IV

\begin{tabular}{|c|c|c|c|c|}
\hline G roup & Animal used & Sex & Body wt. & $T$ reatment \\
\hline Gr-I & Albino rat & M & $200 \mathrm{gms}$ & $\begin{array}{l}\text { Served as control(Normal saline). Once } \\
\text { daily }\end{array}$ \\
\hline Gr-II & Albino rats & M & 200gms & $\begin{array}{l}\text { Served as standard(Glibenclamide } \\
2.5 \mathrm{mg} / \mathrm{kg} \text { )in p.o. Once daily }\end{array}$ \\
\hline Gr-III & Albino rats & M & 200gms & Test drug(p.o/i.p) Dose -1. Once daily \\
\hline Gr-IV & Albino rats & M & 200gms & Test drug(p.o/i.p) Dose-2. Once daily \\
\hline
\end{tabular}

Blood glucose levels were measured in all 5 groups in diff. Time interval like 1, 2, 4, hrs.

Table 4: Overnight fasted animals were grouped in 4 groups of 6 animal each groups

\begin{tabular}{|c|c|c|c|c|}
\hline G roup & Animal used & Sex & Body wt. & Treatment \\
\hline Gr-I & Albino rat & M & $200 \mathrm{gms}$ & $\begin{array}{l}\text { Served as control(Normal saline). Once } \\
\text { daily }\end{array}$ \\
\hline Gr-II & Albino rats & M & $200 \mathrm{gms}$ & $\begin{array}{l}\text { Served as standard(Glibenclamide } \\
2.5 \mathrm{mg} / \mathrm{kg} \text { )in p.o. Once daily }\end{array}$ \\
\hline Gr-III & Albino rats & M & $200 \mathrm{gms}$ & Test drug(p.o/i.p) Dose -1. Once daily \\
\hline Gr-IV & Albino rats & M & $200 \mathrm{gms}$ & Test drug(p.o/i.p) Dose-2. Once daily \\
\hline
\end{tabular}

Blood glucose levels \& body wt. were measured on $0^{\text {th }}, 3^{\text {rd }}, 9^{\text {th }}$ day

Table 5: Overnight fasted animals were grouped in 4 groups of 6 animal each group

\begin{tabular}{lllll}
\hline $\begin{array}{l}\text { Group } \\
\text { Gr-I }\end{array}$ & $\begin{array}{l}\text { Animal used } \\
\text { Albino rat }\end{array}$ & $\begin{array}{l}\text { Sex } \\
\text { M }\end{array}$ & Body wt. & $\begin{array}{l}\text { T reatment } \\
\text { Served as control(Normal saline). } \\
\text { Once daily } \\
\text { Served as standard(Glibenclamide }\end{array}$ \\
Gr-II & Albino rats & M & $200 \mathrm{gms}$ & $\begin{array}{l}\text { 2.5mg/kg)in p.o. Once daily } \\
\text { Test drug(p.o/i.p) Dose }-1 . \text { Once daily } \\
\text { Gr-III }\end{array}$ \\
Albino rats & M & $200 \mathrm{gms}$ & Test drug(p.o/i.p) Dose-2. Once daily \\
\hline
\end{tabular}

Blood glucose levels \& body wt. were measured on $0^{\text {th }}, 7^{\text {th }}, 14^{\text {th }} \& 21^{\text {st }}$ day.

\subsection{Induction of diabetes}

In the present study a single dose of Alloxan in normal saline $120 \mathrm{mg} / \mathrm{kg} \mathrm{b}$. wt was administered intraperitonially. ${ }^{2}$

Diabetes developed gradually was assessed after a week an experiment was carried out to determine the blood sugar levels. Animals with blood sugar levels 200-250 mg/dl, were chosen on $7^{\text {th }}$ day and considered as diabetic rats for antidiabetic screening.

\section{Blood Collection}

A small amount of blood without sacrificing the animal by orbital sinus puncture. The rats were made semi conscious with ether using the sterile capillary tube, puncture the orbital sinus at the inner canthus of the eye, by rotating the capillary tube with sufficient but not excessive pressure, two or three times.

As bleeding starts, the animal was held close to the centrifuge tube, and blood was collected. Applying pressure on the inner canthus for a short while stopped the bleeding. The collected blood was used to determine the biological parameters. $^{5}$

\subsection{Determination blood glucose levels}

A small amount of blood without sacrificing the animals by orbital sinus puncture or by snipping off the tip of the tail. The rats were made semi-conscious with ether using the 
sterile blunt needle; puncture the orbital sinus at the inner canthus of the eye, by rotating the needle with sufficient but not excessive pressure, two or three times as described in sub-acute toxicity study.

As bleeding starts, the animal was held close to the haemogluco test strip and allows the drop of blood to fall on the strip. The bleeding was stopped by applying pressure on the inner canthus for a short while. ${ }^{5}$

The Johnson \& Johnson Ltd. (One touch - Life Scan) glucometer was switched on. When the instrument gives a beep sound after $1 \mathrm{~min}$. The test strip was inserted. Then as bleeding starts, the animal was held close to the haemogluco test strip and allows the drop of blood to fall on the strip. Then the instrument was allowed to react for one minute. Then the blood glucose level was displayed on the screen was recorded.

\subsection{Body weight analysis}

Initial body weight of rats was recorded. The final body weight of rats was recorded on $3^{\text {rd }}$ day, $7^{\text {th }}$ day, $14^{\text {th }}$ day, and $21^{\text {st }}$ day. The $\%$ loss in body weight was calculated after 21 days and the weight variation was noted from treated groups and compared with normal, Alloxan control group.

\subsection{Preparation of serum}

The collected blood was kept at room temperature, refrigerated and centrifuged, for $20 \mathrm{~min}$ at $2000 \mathrm{rpm}$ to separate serum.

\subsection{Biochemical parameters estimated}

Asparate aminotransferase (ASAT)

Alanine Aminotransferase (ALAT)

Alkaline Phosphatase (ALP)

Total Cholesterol (Tc)

High Density Lipid Cholesterol (HDL-C)

Triglyceride (TG)

Total Protein (Tp)

Albumin

Globulin

Total Bilirubin (TB)

Direct Bilirubin (DB)

\subsection{Tranceminases}

\subsubsection{Asparate aminotranceferase(ASAT): ${ }^{6,7}$}

Asparate aminotransferase in serum was assayed using Ecoline dignostic kit. ASAT analyses the following reactions. Glutamate + Oxalacetate Malate + NAD.

The rate of NADH consumption was measured photometrically at $340 \mathrm{~nm}$ and is directly proportional to the ASAT activity in the sample.

Asparate aminotransferase level in serum in expressed as U/L. Glutamine + Pyruvate Lactate + NAD.

\subsubsection{Alanine aminotransferase in serum was assyed} using Ecoline dignostic kit. ALAT analyses the following reaction

The rate of NADH consumption was measured photometrically at $340 \mathrm{~nm}$ and is directly proportional to the ALAT activity in the sample.

Asparate aminotransferase level in serum in expressed as $\mathrm{U} / \mathrm{L}$.

\subsection{Alkaline phosphatase (ALP)}

Alkaline Phosphatase in serum was assayed using Ecoline dignostic kit. ALP analyses the following reaction. Phosphate + 4-nitrophenolate

The rate of increase of 4-nitrophenolate was determined photometrically at $405 \mathrm{~nm}$ and is directly proportional to the ALP activity in the sample.

\subsection{Total cholesterol (Tc): 8,9}

Cholesterol in serum was estimated by CHOD-PAP method using an Ecoline Diagnostic Kit. Cholesterol and its esters are released from lipoproteins by detergents. Cholesterol esterase hydrolyses the esters. In the subsequent enzymatic oxidation by cholesterol osidase, $\mathrm{H}_{2} \mathrm{O}_{2}$ is formed. This converted into a coloured quinonimine in a reaction with 4 aminoantipyrine and phenol catalyzed by peroxidase. The absorbance of the sample and of the standard was measured against the reagent blank value at $546 \mathrm{~mm}$.

Cholesterol level in serum/liver and aorta was expressed as $\mathrm{mg} / \mathrm{dl}$ or $\mathrm{mg} / \mathrm{g}$ tissue.

\subsection{HDL cholesterol}

The HDL cholesterol was separated from Serum after precipitation of LDL and VLDL cholesterol by phosphotungstic acid precipitating reagent.

The supernatant after centrifugation was estimated using Ecoline diagonostic kit by CHOD-PAP method. ${ }^{8,9}$

The absorbance of the sample of the standard was measured against the reagent blank value at $546 \mathrm{~mm}$.

HDL Cholesterol level in serum was expressed as $\mathrm{mg} / \mathrm{dl}$.

\subsection{VLDL cholesterol}

Cholesterol was calculated by the formula ${ }^{10}$

Cholesterol $=$ Triglycerides $/ 5$

Cholesterol level in serum was expressed as $\mathrm{mg} / \mathrm{dl}$

\section{LDL cholesterol}

Cholesterol was calculated by using the formula ${ }^{10}$

Cholesterol $=$ Total Cholesterol $-($ HDL CholesterolTriglycerdes $/ 5$

Cholesterol level in serum was expressed as $\mathrm{mg} / \mathrm{dl}$ 


\subsection{Triglycerides $(T G):^{11}$}

Triglyceride level in serum/liver and aorta was estimated using an Ecoline Diagnostic kit. Glycerol + Fatty acid Glycerol -3 phosphate $+\mathrm{HO}$

The absorbance of the sample and of the standard was measured against the reagent blank value at $546 \mathrm{~nm}$. Triglyceride level in serum/liver and aorta was expressed as $\mathrm{mg} / \mathrm{dl}$ or $\mathrm{mg} / \mathrm{g}$ tissue. ${ }^{8,11}$

Total protein in serum was assayed using Ecoline diagnostic kit. Proteins and peptides in contrast to other nitrogen containing compounds (e.g. creatinine, urea, uric acid.) produce a violet colored complex with copper ions in an alkaline solution. The so-called burette reaction is particularly easy to carry out, giving reproducible results, which are in good agreement with Kjeldahl method.

Measured the absorbance of the sample of the standard against the burret reagent and the absorbance of the blank against water of $546 \mathrm{~nm}$. Total protein level in serum is expressed as $\mathrm{mg} / \mathrm{dl}$.

\subsection{Albumin $^{8,12}$}

Albumin in serum was assayed using Ecoline diagnostic kit.

Albumin forms Blue-green complex with bromocresol green at slightly acidic $\mathrm{PH}$ which is measured photometrically the absorbance of the sample and of the standard against blank at 540-600 $\mathrm{nm}$.

Albumin level is serum is espressed as $\mathrm{g} / \mathrm{dl}$ is recorded.

\subsection{Globulin}

Globulin concentration in serum is indirectly determined by subtracting the albumin concentration from the total protein concentration. ${ }^{13}$

\subsection{Total bilirubin}

Total bilirubin level in serum was assayed using an Ecoline Diagnostic Kit. The total bilirubin in serum is determined by coupling with diazotized sulfanilic acid after the addition of caffeine. Sodium benzoate and sodium acetate. A blue azobilirubin is formed in alkaline Fehlings solution II. This blue compound can also be determined selectively in the presence of yellow by-products (Green mixed coloration) by photometry at $578 \mathrm{~nm}$.

\subsection{Direct bilirubin $^{14}$}

Direct bilirubin in serum was assayed using Ecoline diagnostic kit. The direct bilirubin is measured as the red azo dye at $546 \mathrm{~nm}$ without the addition of alkali. This method is based on the definition of direct bilirubin as the quantity of bilirubin. Which, without the addition of an accelerator, can be determined after a reaction time of 5 minutes? This bilirubin comprises mainly the water soluble bilirubin glucuronides. Under the condition used here, free bilirubin reacts slowly.

Measured the absorbance of sample against blank at 546 nm.

\subsection{Estimation of liver glycogen}

The liver exercised from sub acute toxicity study was subjected to estimate the glycogen.

\subsection{Procedure}

Known weight of the liver tissue was subjected to alkali digestion with $30 \% \mathrm{KOH}$ in boiling water bath for $20 \mathrm{~min}$. $3.0 \mathrm{ml}$ of ethanol was added and tubes were kept in a freezer overnight. They were centrifuged at $3000 \mathrm{rpm}$ for $40 \mathrm{~min}$. The precipitate was dissolved in warm water, reprecipitated with ethanol ad centrifuged again. The final precipitate was dissolved in $3.0 \mathrm{ml}$ of distilled water and heated for $5 \mathrm{~min}$. in a boiling water bath. Aliquots of the sample were mixed with $4.0 \mathrm{ml}$ of Anthrone reagent, heated in a boiling water bath for 20min. The green colour developed was read at $600 \mathrm{~nm}$ using systronics UV-VIS spectrophotometers. ${ }^{15}$ The glycogen content in the tissue is expressed as $\mathrm{mg} / \mathrm{g}$ wet tissue.

\subsubsection{Determination of Hematological parameters}

Hemoglobin concentration in the blood sample was estimated as per the standard procedure. ${ }^{16}$ The $\mathrm{Hb}$ concentration in blood was expressed as gm \%.

\subsubsection{Total W.B.C. count}

Estimation of W.B.C. count was carried out as per the standard procedures. ${ }^{16}$ The W.B.C. count was expressed as number of cells $/ \mu 1$ of whole blood.

\subsubsection{Total R.B.C. count}

Estimation of R.B.C. count was carried out as per the standard procedures (Ghai 1988). ${ }^{17}$ The R.B.C. count was expressed as number of cells/ $\mu 1$ of whole blood.

\subsection{Clotting time}

Clotting time was determined as per the standard procedure by Ghai (1988). ${ }^{15}$ It was expressed in minutes.

\subsection{Statistical analysis}

The values are represented as \pm S.E.M.

The data obtained from various studies were subjected to one- way analysis of variance.(ANOVA) ${ }^{18}$ followed by Dunnet's t-test

\section{Experimental Results \& Discussion}

1. The present study was divided into 9 phases. 
2. In the first phase the Phyllanthus distichus leaves are collected, shed dried and the extracts are prepared using different solvents of increasing polarity by the method of soxeheletion.

3. In the second phase the most potent extract for reduction of blood sugar level in alloxan induced hyperglycemic rats was determined.

4. In the third phase the acute toxicity study was done to determine LD50,

5. In the fourth phase the route of administration was determined in single dose normo/hyperglycemic model.

6. In the fifth phase the hypoglycemic effect and anti diabetic effect of the most potent extract was carried out in normoglycemic. glucose loaded hyperglycemic and alloxan induced diabetic rats in single dose treatment.

7. In the sixth phase the hypoglycemic effect and anti diabetic effect of the extract was carried out in normoglycemic and alloxan induced diabetic rats in multi dose treatment or daily dosing for 21 days study.

8. In the seventh phase the percentage loss in the body weight was calculated and analysed after 21 days in the sub acute toxicity study.

9. In the eighth phase the effect of the extract on the glycogen concentration in liver and kidney was estimated.

10. In the ninth phase the effect of the extract in long term use if any, was carried out by observing the various biochemical parameters, haematological profiles, lipid profiles.

\subsection{Table I Effect of various extracts of leaves of PD on Alloxan induced diabetic rats}

The table I shows that the chloroform extract, aqueous extract \& ethanolic extract registered 3.63\%, $15.51 \%$, $49.84 \%$ decrease in fasting blood glucose levels respectively at the dose level of $100 \mathrm{mg} / \mathrm{kg}$ body wt. in oral route in alloxan induced diabetic rats at the end of $8 \mathrm{hrs}$. However at the same time solvent control(distilled water)\& petroleum ether showed gradual increase in blood sugar level. The standard drug Gibenclamide $(2.5 \mathrm{mg} / \mathrm{kg}$ bwt) posses $60.97 \%$ decrease in blood glucose level at the same time.

The aqueous extract significantly decreases the blood sugar level at the end of $4 \mathrm{hrs} \& 8 \mathrm{hrs}$ in the level of $\mathrm{P}<0.01$, while the ethanolic extract showed significant decrease of blood sugar level starting from $2 \mathrm{hrs}$ to the end of $8 \mathrm{hrs}$ at the level of $\mathrm{P}<0.05$ to $\mathrm{P}<0.001$ when compared with the solvent control. However the standard drug decrease a significant decrease of blood sugar level beginning from $1 \mathrm{hr}$ $(\mathrm{P}<0.05)$ up to $8 \mathrm{hr}(\mathrm{P}<0.001)$ when compared with solvent.

The blood glucose lowering property of ethanolic extract of PD is comparable with the standard drug Gibenclamide (2.5mg/kg Body wt).
Among the tested extract the ethanolic extract at the dose level of $100 \mathrm{mg} / \mathrm{kg}$ through oral route possess highest percentage decrease of blood sugar level.

Therefore the ethanolic extract was selected for the evaluation of hypoglycemic \&/or anti-diabetic activity.

\subsection{Acute toxicity study of ethanolic extract of leaves of $P D$}

The result shown in the Table 7 indicated that the ethanolic extract of PD showed no change of behaviour up to $2 \mathrm{hrs} \&$ no motility was observed up to $24 \mathrm{hrs}$ at the maximum dose levels of $3000 \mathrm{mg} / \mathrm{kg}$. Therefore further studies were carried out at the dose levels of $100 \mathrm{mg} / \mathrm{kg}, 200 \mathrm{mg} / \mathrm{kg}$, \& 300mg/kg body wt.

\subsection{Hypoglycemic activity of ethanolic extract of leaves of $P D$ in single dose treatment in normoglycemic rats in oral route}

The data recorded in the Table 8 showed the test extract possesses $27.11 \%$ \& $33.8 \%$ decrease in blood glucose level at the dose level of $100 \mathrm{mg} / \mathrm{kg} \& 200 \mathrm{mg} / \mathrm{kg}$ b.wt. respectively in oral route at the end of $8 \mathrm{hrs}$. While the standard drug Glibenclamide $(2.5 \mathrm{mg} / \mathrm{kg})$ registered $46.9 \%$ reduction at the same time. However the solvent control group showed negligible reduction of blood glucose level at the end of $8^{\text {th }}$ hrs. The ethanolic extract at the dose level of $100 \mathrm{mg} / \mathrm{kg}$ showed significant decrease $(\mathrm{P}<0.01)$ at $8 \mathrm{hrs}$ while at the same time the dose level $200 \mathrm{mg} / \mathrm{kg}$ showed more significant $(\mathrm{P}<0.001)$ when compared to solvent control.

\subsection{Anti diabetic activity of ethanolic extract of leaves of PD in single dose treatment in alloxan induced Hyperglycemic rats in oral route}

The result expressed in the table iv revealed that the Ethanolic extract in the dose level of $100 \mathrm{mg} / \mathrm{kg} \mathrm{\&} 200 \mathrm{mg} / \mathrm{kg}$ body wt posses $49.67 \%$ \& $55.48 \%$ reduction in the blood glucose level respectively at the end of $8 \mathrm{hr}$ while the standard drug Glibenclamide $(2.5 \mathrm{mg} / \mathrm{kg}$ body wt.) registered $61.01 \%$ decrease in blood sugar level at the same time.

The test extract showed a significant decrease (P0.001) of blood glucose level starting from $4^{\text {th }} \mathrm{hr}$ onward in the tested dose levels while standard drug posses the same rate of significance beginning from $2 \mathrm{hrs}$ while compared with solvent control.

\subsection{Hypoglycemic activity of ethanolic extract of leaves of $P D$ in single dose treatment in glucose loaded hyperglycemic rats in oral route.(OGTT)}

The data recorded in table- $\mathrm{V}$ indicated that the test extract at the dose level of $100 \mathrm{mg} / \mathrm{kg} \& 200 \mathrm{mg} / \mathrm{kg}$ b.wt. registered $19.45 \% \& 23.55 \%$ decrease in blood glucose level at the end 
Table 6: Effects of various Extracts of leaves of P.D on alloxan induced diabetic rats

\begin{tabular}{|c|c|c|c|c|c|c|}
\hline \multirow{2}{*}{$\begin{array}{l}\text { Group \& } \\
\text { treatment }\end{array}$} & \multicolumn{6}{|c|}{ Blood glucose levels(mg/dl) } \\
\hline & Ohrs & 1hrs & $2 \mathrm{hrs}$ & $4 h r s$ & $8 \mathrm{hrs}$ & $\begin{array}{c}\text { \%age decrease at } \\
\text { the end of } 8 \mathrm{hrs}\end{array}$ \\
\hline $\begin{array}{l}\text { I.Solvent } \\
\text { (saline Water) }\end{array}$ & $254.16 \pm 10.55$ & $256 \pm 12.79$ & $277.16 \pm 9.3$ & $289.16 \pm 9.3$ & $294 \pm 10.25$ & \\
\hline $\begin{array}{l}\text { II.Standard } \\
\text { Glibenclamide }\end{array}$ & $\begin{array}{l}246.6 \pm 13.9 \\
\mathrm{mg} / \mathrm{kg})\end{array}$ & $223 \pm 11.45^{*}$ & $200.16 \pm 15.56^{* * *}$ & $135.33 \pm 8.4 * * *$ & $96.16 \pm 6.3^{* * *}$ & 60.97 \\
\hline $\begin{array}{l}\text { III.Pet Ether } \\
\text { Extract } \\
(100 \mathrm{mg} / \mathrm{kg})\end{array}$ & $264 \pm 10.3$ & $270 \pm 10.07$ & $279.67 \pm 9.93$ & $281.5 \pm 5.19$ & $278.5 \pm 6.62$ & \\
\hline $\begin{array}{l}\text { IV.Chloroform } \\
\text { Extract } \\
(100 \mathrm{mg} / \mathrm{kg})\end{array}$ & $275.3 \pm 4.03$ & $272 \pm 6.08$ & $273.16 \pm 8.14$ & $266.67 \pm 8.1$ & $265.84 \pm 7.6$ & 3.63 \\
\hline $\begin{array}{l}\text { V. Ethanol } \\
\text { Extract } \\
(100 \mathrm{mg} / \mathrm{kg})\end{array}$ & $274.83 \pm 6.65$ & $264.5 \pm 6.4$ & $223.34 \pm 11.27 * *$ & $164.83 \pm 12.62 * * *$ & $137.84 \pm 7.95^{* * *}$ & 49.84 \\
\hline $\begin{array}{l}\text { VI.Aquous } \\
\text { Extract } \\
(100 \mathrm{mg} / \mathrm{kg})\end{array}$ & $277.16 \pm 9.7$ & $267.5 \pm 7.3$ & $249 \pm 6.9$ & $246.34 \pm 91 * *$ & $234.16 \pm 4.6^{* *}$ & 15.51 \\
\hline VII. F values & & $2.26^{b}$ & $9.12^{b}$ & $50.93^{b}$ & $119.75^{b}$ & \\
\hline
\end{tabular}

Values are expressed in MEAN \pm S.E.M of six animals. One Way ANOVA followed by Dunnet's t-test.

(F-value denotes statistical significance at $($ ap $<0.05$, bp $<0.01)$

(t-value denotes statistical significance at $* \mathrm{p}<0.05,{ }^{* *} \mathrm{p}<0.01$ and ${ }^{* * *} \mathrm{p}<0.001$ respectively, in comparison to group-I.

Table 7: Acute toxicity study ofethanolic extract of leaves P.D

\begin{tabular}{lclcc}
\hline Group & Dose & Route & No. of Animals & Death \\
I & 500 & ORAL & 4 & 0 \\
II & 1000 & ORAL & 4 & 0 \\
III & 1500 & ORAL & 4 & 0 \\
IV & 2000 & ORAL & 4 & 0 \\
V & 3000 & ORAL & 4 & 0 \\
\hline
\end{tabular}

Table 8: Hypoglycemic activity of ethanolic extract of leaves of P.D in single dose treatment in normoglycemic rats in oral route.

\begin{tabular}{|c|c|c|c|c|c|c|}
\hline \multirow{2}{*}{$\begin{array}{l}\text { Group \& } \\
\text { treatment }\end{array}$} & \multicolumn{6}{|c|}{ Blood glucose levels(mg/dl) } \\
\hline & Ohrs & 1hrs & $2 \mathrm{hrs}$ & $4 h r s$ & 8hrs & $\begin{array}{l}\% \text { age decrease at } \\
\text { the end of } 8 \mathrm{hrs}\end{array}$ \\
\hline $\begin{array}{l}\text { I. Solvent } \\
\text { (saline Water) }\end{array}$ & $104.16 \pm 2.21$ & $104.83 \pm 1.8$ & $102.83 \pm 2.08$ & $106 \pm 1.59$ & $105.66 \pm 1.5$ & \\
\hline $\begin{array}{l}\text { II. Standard } \\
\text { Glibenclamide }\end{array}$ & $\begin{array}{l}103 \pm 2.25 \\
\mathrm{ng} / \mathrm{kg})\end{array}$ & $90 \pm 3.02 * *$ & $84.83 \pm 2.03 * * *$ & $79 \pm 1.5^{* * *}$ & $54.67 \pm 3.67 * * *$ & 46.9 \\
\hline $\begin{array}{l}\text { III. Test-1 } \\
(100 \mathrm{mg} / \mathrm{kg})\end{array}$ & $104.5 \pm 2.01$ & $104.5 \pm 2.4$ & $97.33 \pm 1.89$ & $94.66 \pm 1.96 * *$ & $76.17 \pm 5.14 * * *$ & 27.11 \\
\hline $\begin{array}{l}\text { IV. Test-2 } \\
(200 \mathrm{mg} / \mathrm{kg})\end{array}$ & $104.5 \pm 1.98$ & $104.16 \pm 1.6$ & $96.16 \pm 2.27 *$ & $87.16 \pm 1.9^{* * *}$ & $68.84 \pm 3.47 * * *$ & 33.8 \\
\hline V. F Values & & $9.94^{b}$ & $13.22^{b}$ & $42.01^{b}$ & $34.009^{b}$ & \\
\hline
\end{tabular}

Values are expressed in MEAN \pm S.E.M of six animals. One Way ANOVA followed by Dunnet's t-test.

(F-value denotes statistical significance at $(\mathrm{ap}<0.05, \mathrm{bp}<0.01)$

(t-value denotes statistical significance at $* \mathrm{p}<0.05, * * \mathrm{p}<0.01$ and $* * * \mathrm{p}<0.001$ respectively, in comparison to group-I. 
Table 9: Antidiabetic activity of ethanolic extract of leaves of P.D in single dose treatment in Alloxan induced Hyperglycemic rats in oral route

\begin{tabular}{|c|c|c|c|c|c|c|}
\hline \multirow{2}{*}{$\begin{array}{l}\text { Group \& } \\
\text { treatment }\end{array}$} & \multicolumn{6}{|c|}{ Blood glucose levels(mg/dl) } \\
\hline & Ohrs & 1hrs & 2hrs & $4 h r s$ & 8hrs & $\begin{array}{l}\text { \%age decrease at } \\
\text { the end of } 8 \mathrm{hrs}\end{array}$ \\
\hline $\begin{array}{l}\text { I. Solvent } \\
\text { (saline Water) }\end{array}$ & $254 \pm 10.57$ & $256 \pm 12.79$ & $277.16 \pm 10.97$ & $289.16 \pm 9.3$ & $294 \pm 10.25$ & \\
\hline $\begin{array}{l}\text { II. Standard } \\
\text { Glibenclamide }\end{array}$ & $\begin{array}{l}246.67 \pm 13.9 \\
\mathrm{ng} / \mathrm{kg})\end{array}$ & $234 \pm 12.17$ & $216.83 \pm 18.22 * *$ & $135.34 \pm 8.4 * * *$ & $96.16 \pm 6.3^{* * *}$ & 61.01 \\
\hline $\begin{array}{l}\text { III. Test-1 } \\
(100 \mathrm{mg} / \mathrm{kg})\end{array}$ & $274.83 \pm 6.6$ & $264.16 \pm 6.4$ & $235.5 \pm 5.23 *$ & $168.17 \pm 5.61 * * *$ & $138.34 \pm 3.09 * * *$ & 49.67 \\
\hline $\begin{array}{l}\text { IV. Test-2 } \\
(100 \mathrm{mg} / \mathrm{kg})\end{array}$ & $273.34 \pm 5.4$ & $260.16 \pm 5.1$ & $228.33 \pm 4.3$ & $145.34 \pm 5.4 * * *$ & $121.67 \pm 12.2 * * *$ & 55.48 \\
\hline V. F Values & & 1.9 & $5.5^{b}$ & $92.06^{b}$ & $104.88^{b}$ & \\
\hline
\end{tabular}

Values are expressed in MEAN \pm S.E.M of six animals. One Way ANOVA followed by Dunnet's t-test.

(F-value denotes statistical significance at $(a p<0.05, b p<0.01)$

(t-value denotes statistical significance at $* \mathrm{p}<0.05, * * \mathrm{p}<0.01$ and $* * * \mathrm{p}<0.001$ respectively, in comparison to group-I.

of $4 \mathrm{hrs}$ respectively. While the standard drug Glibenclamide $(2.5 \mathrm{mg} / \mathrm{kg})$ reduces blood glucose level up to $47.28 \%$ at the same time.

At the end of $4 \mathrm{hrs}$. the test extract at both the dose levels bears a significant $(p<0.001)$ decrease of blood glucose in compared with solvent control. While the standard drug Glibenclamide holds the same significancy $(\mathrm{p}<0.001)$ from the beginning from $2 \mathrm{hrs}$

It is observed that the AEPD leaves effectively control the blood sugar level in normal as well as glucose loaded hyperglycemic rats in single dose treated model. Such an effect might be decrease in the rate of initial glucose absorption when the plant fiber is given orally with glucose. ${ }^{18}$ Hence it may be presumed that the glucose lowering effect of the extract was achieved by an extra intestinal ac

\subsection{Hypoglycemic activity of ethanolic extract of leaves of $P D$ in multidose treatment in normoglycemic rat in oral dose}

The purpose of the study is to establish the therapeutic validity of the test extract of P.D. in long term used.

The data showed in this model demonstrated that there was an decrease in blood sugar level in the extent of $28.06 \%$ $\& 33.17 \%$ in case of the test extract at the dose level of 100 $\mathrm{mg} / \mathrm{kg} \& 200 \mathrm{mg} / \mathrm{kg}$ respectively on the $21^{\text {st }}$ day of treatment.

While the standard drug on the same day bears $50.54 \%$ reduction at the same time tested dose levels \& standard drug is $\mathrm{P}<0.0001$ on the $21^{\text {st }}$ day.

The observed data results of the experiments suggested that the Ethanolic extract of P.D. able to maintain the hypoglycemic effect up to 21 st day $\&$ no behavioural changes are observed during the treatment periods.

\subsection{Antidiabetic activity of ethanolic extract of leaves of $P D$ in multidose treatment in alloxan induced Hyperglycemic rats in oral dose.}

The purpose of the study is to confirm the antidiabetic effect of the test extract on longer duration of treatment.

In this model the test extract registered $52.44 \%$ \& $57.58 \%$ of decrease of blood glucose level at the tested dose level of $100 \mathrm{mg} / \mathrm{kg} \& 200 \mathrm{mg} / \mathrm{kg}$ respectively on the $21^{s t}$ day of treatment. While the standard drug showed $60.83 \%$ reduction on the same day.

The test extract bears a significant $\mathrm{P}<0.001$ decrease value of blood sugar level starting from $7^{\text {th }}$ day to $21^{\text {st }}$ day at the both tested dose level while the standard drug showed the same rate significance which started from the $3^{\text {rd }}$ day onwards. When compared with the solvent control.

The study further support the antidiabetic effect of the test extract whose effectiveness persist up to 21 days and the blood sugar level decreases gradually during the observed days, which presumed that the test extract, contains some antidiabetic active principle responsible for this effect.

The hypoglycemic active principle may act probably by initiating the release of insulin from the pancreatic cell of hyperglycemic animal (sulfonyl urea like effect) ${ }^{19}$ the proper mechanism of action is further supported by OGTT in which glucose level reduces in response of test extract.

It is therefore, evident that hypoglycemic principle in the extract, exert a direct effect in diabetic rat probably by a mechanism similar to insulin. Which was substantiated by an extra pancreatic mode of action.

The experiment revealed that A.E. of P.D. $(200 \mathrm{mg} / \mathrm{kg})$ significantly $(\mathrm{P}<0.001)$ decrease the glucose level on hyperglycemic animal. The glucose lowering activity observed in the diabetic animal may due to the stimulation of $\beta$ cells in the pancreatic islets. 
Table 10: Hypoglycemic activity of ethanolic extract of leaves of P.D in single dose treatment in glucose loaded hyperglycemic rats in oral route.(OGTT)

\begin{tabular}{|c|c|c|c|c|c|c|}
\hline \multirow{2}{*}{$\begin{array}{l}\text { Group \& } \\
\text { treatment }\end{array}$} & \multicolumn{6}{|c|}{ Blood glucose levels(mg/dl) } \\
\hline & $-60 \mathrm{~min}$ & Ohrs & 1hrs & $2 \mathrm{hrs}$ & 4hrs & $\begin{array}{l}\text { \% age decrease at } \\
\text { the end of } 8 \mathrm{hrs}\end{array}$ \\
\hline $\begin{array}{l}\text { I. Solvent } \\
\text { (saline Water) }\end{array}$ & $104.16 \pm 2.21$ & $107.83 \pm .8$ & $123.33 \pm 2.4$ & $136 \pm 2.8$ & $103.33 \pm 1.9$ & \\
\hline $\begin{array}{l}\text { II. Standard } \\
\text { Glibenclamide }\end{array}$ & $\begin{array}{l}104.33 \pm 2.26 \\
\mathrm{ng} / \mathrm{kg})\end{array}$ & $90 \pm 3.02 * * *$ & $78.83 \pm 2.2 * * *$ & $66 \pm 4.04 * * *$ & $55 \pm 4.3 * * *$ & 47.28 \\
\hline $\begin{array}{l}\text { III. Test-1 } \\
(100 \mathrm{mg} / \mathrm{kg})\end{array}$ & $104.5 \pm 2.0$ & $102.16 \pm 1.8$ & $92.67 \pm 2.4 * * *$ & $89.16 \pm 2.08 * * *$ & $84.17 \pm 2.8^{* * *}$ & 19.45 \\
\hline $\begin{array}{l}\text { IV. Test-2 } \\
(200 \mathrm{mg} / \mathrm{kg})\end{array}$ & $104 \pm 1.98$ & $96.16 \pm 2.7 * *$ & $88.84 \pm 2.7 * * *$ & $82.16 \pm 2.6^{* * *}$ & $79.5 \pm 2.2 * * *$ & 23.55 \\
\hline V. F Values & & $11.26^{b}$ & $60.47^{b}$ & $99.96^{b}$ & $44.26^{b}$ & \\
\hline
\end{tabular}

Values are expressed in MEAN \pm S.E.M of six animals. One Way ANOVA followed by Dunnet's t-test.

(F-value denotes statistical significance at $(\mathrm{ap}<0.05, \mathrm{bp}<0.01)$

(t-value denotes statistical significance at $* \mathrm{p}<0.05,{ }^{*} \mathrm{p}<0.01$ and ${ }^{* * *} \mathrm{p}<0.001$ respectively, in comparison to group-I.

Table 11: Hypoglycemic activity of ethanolic extract of leaves of P.D in multidose treatment in normoglycemic rats in oral dose

\begin{tabular}{lccccc}
\hline Group \& treatment & \multicolumn{5}{c}{ Blood glucose levels(mg/dl) } \\
& $\mathbf{0}^{\text {th }}$ day & ${7^{t h} \text { day }}^{\text {th }} \mathbf{1 4}^{\text {th day }}$ & $\mathbf{2 1}^{\text {st }}$ day & $\begin{array}{c}\text { \%age decrease at the end of } \\
\mathbf{8 h r s}\end{array}$ \\
I. Solvent (saline Water) & $104.66 \pm 2.85$ & $104.83 \pm 2.07$ & $104.66 \pm 1.7$ & $105.5 \pm 2.2$ & \\
II. Standard & $106.16 \pm 2.28$ & $86.16 \pm 3.13^{* * *}$ & $68.5 \pm 3.8^{* * *}$ & $52.5 \pm 2.6^{* * *}$ & \\
Glibenclamide(2.5mg/kg) & & & & & \\
III. Test-1 (100mg/kg) & $104.5 \pm 2.5$ & $101.66 \pm 1.7$ & $91.83 \pm 1.9^{* *}$ & $75.17 \pm 4.5^{* * *}$ & 28.06 \\
IV. Test-2 (200mg/kg) & $104 \pm 2.0$ & $98.83 \pm 1.8$ & $85.34 \pm 2.6^{* * *}$ & $69.5 \pm 2.9^{* * *}$ & 33.17 \\
V. F Values & & $13.01^{b}$ & $31.62^{b}$ & $47.2^{b}$ & \\
\hline
\end{tabular}

Values are expressed in MEAN \pm S.E.M of six animals. One Way ANOVA followed by Dunnet's t-test.

(F-value denotes statistical significance at ap $<0.05$, bp $<0.01$ )

(t-value denotes statistical significance at $* \mathrm{p}<0.05, * * \mathrm{p}<0.01$ and $* * * \mathrm{p}<0.001$ respectively, in comparison to group-I.

Table 12: Antidiabetic activity of ethanolic extract of leaves of P.D in multidose treatment in alloxan induced Hyperglycemic rats in oral dose

\begin{tabular}{|c|c|c|c|c|c|c|}
\hline \multirow{2}{*}{$\begin{array}{l}\text { Group \& } \\
\text { treatment }\end{array}$} & \multicolumn{6}{|c|}{ Blood glucose levels(mg/dl) } \\
\hline & $\mathbf{0}^{t h}$ day & $\mathbf{3}^{r d}$ day & $7^{\text {th }}$ day & $14^{t h}$ day & $21^{s t}$ day & $\begin{array}{c}\% \text { age decrease at } \\
\text { the end of } 8 \mathrm{hrs}\end{array}$ \\
\hline $\begin{array}{l}\text { I. Solvent } \\
\text { (saline Water) }\end{array}$ & $275.5 \pm 5.6$ & $265 \pm 6.5$ & $253.16 \pm 5.8$ & $238.34 \pm 6.1$ & $238.34 \pm 6.1$ & \\
\hline $\begin{array}{l}\text { II. Standard } \\
\text { Glibenclamide }\end{array}$ & $\begin{array}{l}274.5 \pm 3.6 \\
\mathrm{~g} / \mathrm{kg})\end{array}$ & $227.16 \pm 4.9 * * *$ & $182.5 \pm 6.7 * * *$ & $156.34 \pm 5.4 * * *$ & $107.5 \pm 4.07$ & 60.83 \\
\hline $\begin{array}{l}\text { III. Test-1 } \\
(100 \mathrm{mg} / \mathrm{kg})\end{array}$ & $279 \pm 4.5$ & $263.83 \pm 4.6$ & $233.16 \pm 5.7^{*}$ & $180.5 \pm 5.4^{* * *}$ & $132.67 \pm 4.02^{* * *}$ & 52.44 \\
\hline $\begin{array}{l}\text { IV. Test-2 } \\
(200 \mathrm{mg} / \mathrm{kg})\end{array}$ & $280.16 \pm 4.8$ & $263 \pm 4.3$ & $226.33 \pm 6.5^{* *}$ & $173.16 \pm 3.67 * * *$ & $118.83 \pm 2.9 * * *$ & 57.58 \\
\hline V. F Values & & $12.58^{b}$ & $22.83^{b}$ & $45.71^{b}$ & $159.99^{b}$ & \\
\hline
\end{tabular}

Values are expressed in MEAN \pm S.E.M of six animals. One Way ANOVA followed by Dunnet's t-test.

(F-value denotes statistical significance at $(\mathrm{ap}<0.05, \mathrm{bp}<0.01)$

(t-value denotes statistical significance at $* \mathrm{p}<0.05, * * \mathrm{p}<0.01$ and $* * * \mathrm{p}<0.001$ respectively, in comparison to group-I. 


\subsection{Percentage loss in body weight in ethanolic extracts of leaves of $P D$ in alloxan induced diabetic rats}

The content of Table 13 indicates that there was decrease \% loss in body wt. when measured on $3^{\text {rd }} 7^{\text {th }} 14^{\text {th }} \& 21^{\text {st }}$ day of treatment in both tested dose levels.

The test extract at $100 \mathrm{mg} / \mathrm{kg}$ posses $6.72 \%$ loss of body wt. on $21^{\text {st }}$ day. While on $3^{\text {rd }}$ day the $\%$ loss of body wt. registered $12 \%$. Similarly at dose level of $200 \mathrm{mg} / \mathrm{kg}$ between, on $21^{\text {st }}$ day measured $5.55 \%$ loss of body wt while on $3^{r d}$ day $\%$ loss of body wt registered $10 \%$.

However Glibenclamide $(2.5 \mathrm{mg} / \mathrm{kg})$ reduces the body wt by $3.33 \%$ at the end of $21^{\text {st }}$ days while the solvent control represented gradual increase in $\%$ loss of body wt. up to 21 days i.e. $21^{s t}$ day the loss was $25.33 \%$ where as on $3^{\text {rd }}$ day the loss was $10 \%$.

It has been reported that diabetes is a heterogeneous metabolic disorder in which one of the symptomatic character is loss in body wt. It has been stated that DM causes failure to use of glucose for energy leads to increased utilization \& decreased storage of proteins responsible for reduction of body wt. essentially by depletion of the body proteins. ${ }^{17}$

The results of the study presented that the decreased loss of body wt. might be contributed by increased use of glucose by the tissue.

\subsection{Effect of ethanolic extract of leaves of PD on the glycogen conc. in liver \& kidney}

The data presented in Table 14 demonstrated that the glycogen content of liver \& kidney of DM animals treated with Ethanolic extract of leaves of PD \& standard drug were significantly increased when compared with solvent control at the end of 21 days of treatment, even the test extract \& standard drug approaches the content of glycogen towards normal glycogen level. It was reported that hyperglycemia results in decreased glucose utilization and glycogen synthesis. ${ }^{17}$

\subsection{Effect of ethanolic extract of PD on lipid profile in Sub acute toxicity}

The observation data should in Table 15 present significant $(\mathrm{P}<0.01)$ reduction of total cholesterol in serum in the groups treated with test extraction \& standard drug when compared with solvent control.

The extent of reduction in both the close level of test extract was dose dependent. In case of triglycerides level \& standard drug Glibenclamide $(2.5 \mathrm{mg} / \mathrm{kg}$ body wt.) reduces significantly $(\mathrm{P}<0.001)$ when compared with solvent control. All the above studies were carried out on the $21^{s t}$ day of treatment.

However, the value of HDL in case of test extract at tested dose levels \& standard showed increased value than that of solvent control group with a significant level. While the LDL \& VLDL levels significantly $(\mathrm{P}<0.001)$ decrease in all drug treated groups when compared with solvent control.

It has been reported that in the untreated or under treated diabetic patients, hyperglyceridemia \& hypercholesterolemia often occur due to the increase production of VLDL \& due to unavailability of lipoprotein lipase which hydrolyses the triglycerides to VLDL because of insulin deficiency. ${ }^{20}$

As the test extract reduces VLDL, TC \& TG. Hence it might be presumed that the test extract is responsible for the enhancement of the transcription of lipoprotein lipase, similar to insulin.

\subsection{Effect of ethanolic extract of leaves of PD on hematological parameters in sub acute toxicity study}

However, the diabetic rats treated with solvent showed a decrease value of $\mathrm{RBC}, \mathrm{WBC}, \& \mathrm{Hb}$. Content when compared with normal.

The hematological parameters exhibited in Table 16 showed that the animals treated with standard drug Glibenclamide \& test extract in the tested dose levels bears normal value in $\mathrm{RBC}$ count \& $\mathrm{Hb}$. Count. Whereas the clotting time slightly elevated than normal. However, the diabetic rats treated with solvent showed a decrease value of RBC, WBC \& Hb. Content when compared with normal.

The neutrofil count appears to nearly equal with that of normal value. The other hematological parameters like Esonophil, lymphocyte \& monocytes in case of the standard drug \& test extract treated animals did not show any alteration.

Therefore, it might be suggested that the test extracts has no significant effect on the hematological parameters \& is evident for the safely used at the ethanolic extract of P.D. leaves for a longer duration time.

\subsection{Effect of ethanolic extract of leaves of PD on biochemical parameters in sub acute toxicity study}

From the Table 17, the data showed ASAT \& ALAT enzymes activity of alloxan induced diabetic rats showed significantly higher than normal rats. The test extract treated rats at tested dose levels had reduced enzymes activity when compared with diabetic rats.

The total protein \& total albumin content serum was significantly lowered in diabetic rats when compared with solvent control but in the drug treated diabetic animals it returned to nearly normal.

The present study of experimental approach has been conducted for the test extract to elicit tonic response over an exposure period of 21 days. Alteration in the marker enzymes like ASAT, ALAT, ALP, liver \& kidney glycogen content.

The total protein, lipid profile properties like TC, TG, HDL, LDL, VLDL of the extract were determined. The 
Table 13: Percentage loss in body weight in ethanolic extract of leaves of P.D in alloxan induced diabetic rats

\begin{tabular}{lcccc}
\hline Group \& treatment & \multicolumn{2}{c}{ Body weight loss in percentage } \\
$\mathbf{1}^{\text {th }}$ day & $\mathbf{7}^{\text {rd }}$ day & 16 & 18.66 & $\mathbf{2 1}^{\text {st }} \mathbf{d a y}^{\text {day }}$ \\
I. Solvent (saline Water) & 10 & 6.66 & 6.66 & 25.33 \\
II. Standard & 8 & & & 3.33 \\
Glibenclamide(2.5mg/kg) & 12 & 10.11 & 8.0 & 6.72 \\
III. Test-1 (100mg/kg) & 10 & 8.23 & 6.38 & 5.55 \\
IV. Test-2 (200mg/kg) & & & \\
\hline
\end{tabular}

Table 14: Effect of ethanolic extract of leaves of P.D on the glycogen conc. in liver \& kidney

\begin{tabular}{lcc}
\hline Group \& treatment & Liver Glycogen $\mathbf{~ m g} / \mathbf{g m}$ tissue & Kidney glycogen mg/gm tissue \\
I.Solvent (saline Water) & $19.16 \pm 2.21$ & $11.48 \pm 1.5$ \\
II.Standard Glibenclamide $(2.5 \mathrm{mg} / \mathrm{kg})$ & $33.66 \pm 2.76^{* *}$ & $17.5 \pm 1.8^{*}$ \\
III.Normal & $35.67 \pm 2.7$ & $19.4 \pm 1.4$ \\
IV. Test-I $(100 \mathrm{mg} / \mathrm{kg})$ & $28.46 \pm 1.19^{*}$ & $13.6 \pm 2.2$ \\
V. Test-II $(200 \mathrm{mg} / \mathrm{kg})$ & $31.8 \pm 4.4^{* *}$ & $15.67 \pm 1.67$ \\
VI.F Values & $5.21^{b}$ & $3.14^{a}$ \\
\hline
\end{tabular}

Values are expressed in MEAN \pm S.E.M of six animals. One Way ANOVA followed by Dunnet's t-test.

(F-value denotes statistical significance at $(a p<0.05, b p<0.01)$

(t-value denotes statistical significance at $* \mathrm{p}<0.05, * * \mathrm{p}<0.01$ and $* * * \mathrm{p}<0.001$ respectively, in comparison to group-I.

Table 15: Effect of ethanolic extract of P.D on lipid profile in Sub acute toxicity

\begin{tabular}{|c|c|c|c|c|c|}
\hline $\begin{array}{l}\text { Group \& } \\
\text { treatment }\end{array}$ & TC mg/dl & TGmg/dl & $\begin{array}{l}\text { Lipid Profile } \\
\text { HDLmg/dl }\end{array}$ & LDLmg/dl & VLDLmg/dl \\
\hline $\begin{array}{l}\text { I.Solvent (saline } \\
\text { Water) }\end{array}$ & $227.83 \pm 5.6$ & $182 \pm 6.7$ & $35.16 \pm 4.4$ & $164.83 \pm 6.4$ & $44.66 \pm 3.12$ \\
\hline \multicolumn{6}{|c|}{ Glibenclamide $(2.5 \mathrm{mg} / \mathrm{kg})$} \\
\hline III.Normal & $138.84 \pm 4.3$ & $89.16 \pm 17$ & $51.67 \pm 3.4$ & $67.17 \pm 4.9$ & $17.16 \pm 3.0$ \\
\hline $\begin{array}{l}\text { IV. Test-I } \\
(100 \mathrm{mg} / \mathrm{kg})\end{array}$ & $211.17 \pm 4.13$ & $156.83 \pm 5.01 * *$ & $39.17 \pm 4.8$ & $146.67 \pm 5.8$ & $32.67 \pm 2.6^{*}$ \\
\hline $\begin{array}{l}\text { V. Test-II } \\
(200 \mathrm{mg} / \mathrm{kg})\end{array}$ & $203.47 \pm 5.7 * *$ & $148.34 \pm 4.8^{* * * *}$ & $41.17 \pm 3.7$ & $136.83 \pm 4.4^{* *}$ & $31.34 \pm 2.3 * *$ \\
\hline VI.F Values & $55.027^{b}$ & $54.53^{b}$ & $2.76^{a}$ & $57.79^{b}$ & $1351^{b}$ \\
\hline
\end{tabular}

Values are expressed in MEAN \pm S.E.M of six animals. One Way ANOVA followed by Dunnet's t-test.

(F-value denotes statistical significance at $(\mathrm{ap}<0.05, \mathrm{bp}<0.01)$

(t-value denotes statistical significance at $* \mathrm{p}<0.05, * * \mathrm{p}<0.01$ and $* * * \mathrm{p}<0.001$ respectively, in comparison to group-I.

Table 16: Effect of ethanolic extract of leaves of P.D on Hematological Parameters in sub acute toxicity study

\begin{tabular}{|c|c|c|c|c|c|c|c|c|}
\hline $\begin{array}{l}\text { Group \& } \\
\text { treatment }\end{array}$ & $\underset{\text { (millions/ml) }}{\text { RBC }}$ & $\begin{array}{c}\text { WBC } \\
\text { (millions/ml) }\end{array}$ & Hb (g/dl) & $\begin{array}{c}\text { Clotting } \\
\text { Time(min) }\end{array}$ & $\begin{array}{c}\text { Neutrofil } \\
(\%)\end{array}$ & $\begin{array}{c}\text { Esonophil } \\
(\%)\end{array}$ & $\begin{array}{c}\text { Lymphocyte } \\
(\%)\end{array}$ & $\begin{array}{c}\text { Monocyte } \\
(\%)\end{array}$ \\
\hline $\begin{array}{l}\text { I.Solvent } \\
\text { (saline } \\
\text { Water) }\end{array}$ & $2.6 \pm .42$ & $7.8 \pm .9$ & $7.34 \pm 1.5$ & $1.41 \pm .009$ & $21.16 \pm 3.7$ & $4.75 \pm .68$ & $72.67 \pm 4.5$ & $4.6 \pm .7$ \\
\hline $\begin{array}{l}\text { II.Standard } \\
\text { Glibenclamic }\end{array}$ & $\begin{array}{c}4.8 \pm .6^{*} \\
\mathrm{e}(2.5 \mathrm{mg} / \mathrm{kg})\end{array}$ & $6.8 \pm 1.1$ & $10.67 \pm 1.2$ & $1.07 \pm .08$ & $27.83 \pm 2.3$ & $1.91 \pm .45^{* * *}$ & $69.84 \pm 3.3$ & $2.8 \pm .7$ \\
\hline III.Normal & $5.1 \pm .6$ & $7.1 \pm 1.24$ & $11.84 \pm 1.4$ & $1.05 \pm .07$ & $32.67 \pm 1.5$ & $1.55 \pm .07$ & $68.67 \pm 3.3$ & $1.9 \pm .2$ \\
\hline $\begin{array}{l}\text { IV. Test-I } \\
(100 \mathrm{mg} / \mathrm{kg})\end{array}$ & $3.6 \pm .8$ & $6.1 \pm .4$ & $8.34 \pm 1.5$ & $1.35 \pm .07$ & $24.34 \pm 2.1$ & $2.6 \pm .3 * *$ & $71.34 \pm 4.1$ & $3.67 \pm .9$ \\
\hline $\begin{array}{l}\text { V. Test-II } \\
(200 \mathrm{mg} / \mathrm{kg})\end{array}$ & $4.16 \pm .65$ & $6.5 \pm .7$ & $8.84 \pm 1.2$ & $1.25 \pm .07$ & $26.5 \pm 1.6$ & $2.1 \pm .4^{* *}$ & $70.33 \pm 3.9$ & $3.2 \pm .3$ \\
\hline $\begin{array}{l}\text { VI.F } \\
\text { Values }\end{array}$ & $2.7^{a}$ & .45 & 1.6 & $3.87^{a}$ & $3.1^{a}$ & $8.4^{b}$ & 0.15 & 2.17 \\
\hline
\end{tabular}

Values are expressed in MEAN \pm S.E.M of six animals. One Way ANOVA followed by Dunnet's t-test.

(F-value denotes statistical significance at $(\mathrm{ap}<0.05, \mathrm{bp}<0.01)$

(t-value denotes statistical significance at $* \mathrm{p}<0.05, * * \mathrm{p}<0.01$ and $* * * \mathrm{p}<0.001$ respectively, in comparison to group-I. 
Table 17: Effect of ethanolic extract of leaves of P.D on Biochemical parameters in sub acute toxicity study

\begin{tabular}{lccccc}
\hline Group \& treatment & ASAT $(\mu \mathbf{l})$ & ALAT $(\mu \mathbf{l})$ & ALP $(\mu \mathbf{l})$ & Aibumin(gm/dl) & $\begin{array}{c}\text { Total } \\
\text { protein }(\mathbf{g m . d l})\end{array}$ \\
& & & & $5.75 \pm .77$ & $6.24 \pm 1.03$ \\
I.Solvent (saline Water) & $38.16 \pm 3.8$ & $49.67 \pm 4.09$ & $291.5 \pm 4.5$ & 5.84 .79 & $4.2 \pm .81$ \\
II.Standard & $25.17 \pm 3.2^{*}$ & $31.34 \pm 2.3^{* *}$ & $270.84 \pm 4.9^{*}$ & & \\
Glibenclamide(2.5mg/kg) & & & & $3.4 \pm .37$ & $8.08 \pm .52$ \\
III.Normal & $22.84 \pm 3.87$ & $28.34 \pm 3.4$ & $262.17 \pm 6.05$ & $5.14 \pm .8$ \\
IV. Test-I (100mg/kg) & $36.84 \pm 3.87$ & $39.84 \pm 2.98^{*}$ & $280.17 \pm 5.02$ & 5.79 & $5.67 \pm .68$ \\
V. Test-II (200mg/kg) & $30.67 \pm 3.1$ & $35.67 \pm 2.24^{* *}$ & $275.16 \pm 4.49^{*}$ & $4.7 \pm .67$ & $2.78^{a}$ \\
VI.F Values & $3.86^{a}$ & $7.24^{b}$ & $4.67^{b}$ & 1.71 & \\
\hline
\end{tabular}

Values are expressed in MEAN \pm S.E.M of six animals. One Way ANOVA followed by Dunnet's t-test.

(F-value denotes statistical significance at ap $<0.05, \mathrm{bp}<0.01$ )

$(\mathrm{t}-\mathrm{value}$ denotes statistical significance at $* \mathrm{p}<0.05, * * \mathrm{p}<0.01$ and $* * * \mathrm{p}<0.001$ respectively, in comparison to group-I.

leaves of P.D. didn't produce any toxic or cells damaging effect to animals.

\section{Conclusion}

The ethanolic extract of leaves of Phyllanthus distichus results maximum yield value than that of petroleum ether extract, chloroform extract through successive extraction process. The ethanolic extract of leaves of Phyllanthus distichus showed maximum control in blood sugar in hyperglycemic wistar rats than other experimental extracts. The test extract also reduces the blood sugar level to a maximum extent in case of normal animals. Among the study of effects of AEPD leaves in both normoglycemic and hyperglycemic model through oral route. Toxicological study revealed that the AEPD leaves were safe and does not alter normal physiological and behavioral effect even at a higher dose level of $3000 \mathrm{mg} / \mathrm{kg}$ body weight.

Administration of AEPD significantly reduces the elevated glucose level in alloxan induced diabetic rats confirms its anti-diabetic activity. This also reduces normal glucose level, which reveals the hypoglycemic property. The whole protein, whole cholesterol, ASAT, ALAT, ALP enzyme activity of alloxan administered rats showed significantly higher than normal rats, the test extract treated rats significantly reduced the elevated levels. The results of the present investigation indicate that the AEPD leaves may have a place in the therapy of DM as anti-diabetic and/or hypoglycemic agent. The hypoglycemic and/or anti-diabetic effect of the test extract may be due to the influence on glycogenesis, glycogenolysis metabolic activity property of one or more of its constituents.

Thus it is concluded that the ethanolic extract of leaves of Phyllanthus distichus beneficial in lowering the blood sugar concentration and in management of other diabetic complications without any doubt.

\section{Source of Funding}

None.

\section{Conflict of Interest}

There is no conflict of interest among the authors.

\section{References}

1. Al-Ahmed FAA, El-Denshary ESM, Zaki M, El-Sawaf HA, AbuJayyab AR. Interaction between diazepam and oral antidiabetic agents on serum glucose, insulin and chromium levels in rats. Biosci Rep. 1989;9:347-50.

2. Dash GK, Suresh P, Ganapati S. Studies on hypoglycacmic and wound healing activities of lantana camara linn. J Nat Remedies. 2001;1:10510 .

3. Ghosh M. Fundamentals of experimental pharmacology. 2nd ed. Calcutta: Scientific Book Agency; 1984.

4. Riley H, Spinks A. Biological assessment of tranquillisers. Part I. J Pharmacol. 1956;p. 657-71.

5. Jaiprakash R, Nagarani MA, Venkatraman BV. Effect of felodipine on cholinergic responses of the colonic smooth muscle of streptozotocin induced diabetic rats. Indian J Exp Biol. 1995;33(4):297-9.

6. Bergmeyer HU. Standardization of Enzyme Assays. Clin Chem. 1972;18(11):1305-11.

7. Richmond W. Preparation and properties of a cholesterol oxidase from Nocardia sp. and its application to the enzymatic assay of total cholesterol in serum. Clin Chem. 1972;19(12):1350-6.

8. Hendry R. Clinical chemistry. New York: Harper and Row Publishers; 1964.

9. Friedwald WT, Levy RI, Fredrickson DS. Estimation of the Concentration of Low-Density Lipoprotein Cholesterol in Plasma, Without Use of the Preparative Ultracentrifug. Clin Chem. 1972;6(1):499-502.

10. Schettler G, Nussel E. Maßnahmen zur Prävention der Arteriosklerose. Arb Med Soz Med Prav Med. 1975;10:25.

11. Josephson G, Gyllensward C. The development of the protein fractions and of cholesterol concentration in the serum of normal infants and children. Scand J Clin Lab Invest. 1957;9(1):29-38.

12. Weichselbaum TE. An accurate and rapid method for the determination of proteins in small amounts of blood serum and plasma. Am J Clin Pathol. 1946;10:40-9.

13. Sood R. Medical laboratory technology, methods and interpretations. 5th ed.; 2003

14. Morales MA, Jabbagy A, Terenzi HF. Mutations affecting accumulation of glycogen. Fungal Genet Rep. 1973;20.

15. Ghai CL. A text book of practical physiology; 1998.

16. Kuikarni S. Handbook of experimental pharmacology. 2nd ed.; 1993.

17. Seth SD, Livingstone BI. 1999.

18. Chirdchupunseree H, Pramyothin P. Protective activity of phyllanthin in ethanol-treated primary culture of rat hepatocytes. $J$ Ethnopharmacol. 2010;128(1):172-6.

19. Available from: www.DiabetesIndia.com.

20. Haardman JG, Limbird LE, Gilman AG. 1690. 


\section{Author biography}

Debashis Mohapatra Assistant Professor

Sunita Mishra Assistant Professor
Cite this article: Mohapatra D, Mishra S. Hypoglycemic and

antidiabetic evaluation of leaves of phyllanthus distichus in normal and

alloxan induced diabetic rats. Indian J Pharm Pharmacol 2020;7(3):189-202. 